\title{
DEVELOPMENT AND VALIDATION OF UV SPECTROPHOTOMETRIC METHOD FOR DETERMINATION OF LEVOFLOXACIN IN PHARMACEUTICAL DOSAGE FORMS
}

\author{
Nájla Mohamad Kassab* \\ Departamento de Farmácia Bioquímica, Centro de Ciências Biológicas e da Saúde, Universidade Federal de Mato Grosso do Sul, \\ CP 549, 79070-900 Campo Grande - MS, Brasil \\ Marcos Serrou do Amaral \\ Departamento de Física, Centro de Ciências Exatas e Tecnologia, Universidade Federal de Mato Grosso do Sul, CP 549, \\ 79070-900 Campo Grande - MS, Brasil \\ Anil Kumar Singh e Maria Inês Rocha Miritello Santoro \\ Departamento de Farmácia, Faculdade de Ciências Farmacêuticas, Universidade de São Paulo, CP 66083, 05315-970 São Paulo \\ - SP, Brasil \\ Recebido em 7/7/09; aceito em 25/11/09; publicado na web em 23/3/10

\begin{abstract}
The objective of this research was to develop and validate an alternative analytical method for quantitative determination of levofloxacin in tablets and injection preparations. The calibration curves were linear over a concentration range from 3.0 to $8.0 \mu \mathrm{g} \mathrm{mL} \mathrm{m}^{-1}$. The relative standard deviation was below $1.0 \%$ for both formulations and average recovery was $101.42 \pm 0.45 \%$ and $100.34 \pm 0.85 \%$ for tablets and injection formulations, respectively. The limit of detection and limit of quantitation were 0.08 and $0.25 \mu \mathrm{gLL}^{-1}$, respectively. It was concluded that the developed method is suitable for the quality control of levofloxacin in pharmaceuticals formulations.
\end{abstract}

Keywords: fluoroquinolone; UV spectrophotometry; quality control.

\section{INTRODUCTION}

Quinolones are antimicrobials, structurally related to nalidixic acid, which were made available for clinical use in urinary infections, since 1960s. ${ }^{1,2}$ They are used in human and veterinary medicine, especially in animal breeding area. ${ }^{1,2}$ Considerable amounts of quinolones are widely used under field conditions (in poultry, swine, and cattle production), both in the treatment of infections and as growth promoters. ${ }^{1}$ The bactericidal activity of levofloxacin is mediated by the inhibition of DNA gyrase (topoisomerase II) and topoisomerase IV, essential enzymes involved in bacterial DNA replication, transcription, repair and recombination. ${ }^{3}$

Levofloxacin (Figure 1, CAS number 100986-85-4) is pure (-)-(S)enantiomer of the racemic drug substance ofloxacin, which was introduced in 1997. A third-generation fluoroquinolone with a wide spectrum of action against gram-positive and gram-negative bacteria, anaerobic microorganisms, and atypical pathogens. ${ }^{4}$ Levofloxacin prepared as hemihydrate, whose molecular mass is $369.93 \mathrm{~g} \mathrm{~mol}^{-1}$, is presented as white to light yellow needlelike crystals, that melt at approximately $226^{\circ} \mathrm{C}$. Its solubility is nearly constant from $\mathrm{pH} 0.6$ to $5.8(100.0 \mathrm{mg}$ $\left.\mathrm{mL}^{-1}\right)$. Above $\mathrm{pH} 5.8$, solubility increases sharply, reaching a maximum of $272 \mathrm{mg} \mathrm{mL}^{-1}$ at $\mathrm{pH} 6.7$, beyond which it decreases to a minimum of $50.0 \mathrm{mg} \mathrm{mL}{ }^{-1} .5$ Levofloxacin is the quinolone of choice for airway infections, being active against several types of pathogens. ${ }^{1,2,4,6}$<smiles>C[C@H]1COc2c(N3CCN(C)CC3)c(F)cc3c(=O)c(C(=O)O)cn1c23</smiles>

Figure 1. Chemical structure of Levofloxacin

\footnotetext{
*e-mail: nmkassab@gmail.com
}

Various analytical methods have been reported in scientific literature for the analysis of levofloxacin in pharmaceutical formulation and/or biological fluids including high-performance liquid-chromatography with UV detection (HPLC-UV), ${ }^{7}$ vibrational spectroscopy, ${ }^{8}$ spectrofluorimetry (SF), ${ }^{9}$ colorimetric spectrophotometry (CS), ${ }^{9,10}$ spectrophotometry by ion-pair complex (CIPS), ${ }^{10-12}$ and UV spectrophotometry (UVS). ${ }^{13}$

Most spectrophotometric methods in the literature for analysis of levofloxacin is based on the formation of ion-complexes, ${ }^{10-12}$ which use dye as Eriochrome black, ${ }^{12}$ bromophenol blue, bromocresol green, ${ }^{10,12}$ eosin, merbromin ${ }^{11}$ and chromogenic reagent such as Folin-Ciocalteau. ${ }^{12}$ The addition of these substances usually increases the cost of analysis and sample preparation is time consuming. Besides cost, toxicity of reagents and solvents used in the analysis should also be considered. Exposure to merbromin even at low concentrations and short exposure time can cause poisoning. The complexes formed normally need extraction with organic solvents, for example, chloroform, ${ }^{10,12}$ which in addition to further increase the cost of analysis and require safe handling and proper disposal.

Recently an UVS method was proposed with acetonitrile as solvent for the quantitative determination of levofloxacin in tablets and solution..$^{13}$ This solvent is more toxic and more expensive than methanol. Therefore, the proposed method is less toxic to the analyst when compared with the solvent acetonitrile and is more economical.

In addition, there are no official methods for determination of this active substance. ${ }^{14,15}$

Thus, the aim of this study was to develop and validate a fast, simple and cost-effective UV-spectrophotometric alternative method for analysis of two commercial formulations of levofloxacin.

\section{EXPERIMENTAL}

\section{Material}

The levofloxacin reference substance (assigned purity 100.0\%) and levofloxacin pharmaceutical dosage forms were kindly donated by local pharmaceutical industries and were used as reference stan- 
dards without further purification. The commercial levofloxacin (free base) dosage forms used were tablets containing $250 \mathrm{mg}$ of the active substance (declared content), and injection vial of $100 \mathrm{~mL}$, with $5 \mathrm{mg}$ $\mathrm{mL}^{-1}$ (declared concentration). The levofloxacin reference substance, as well as the tablets and injection vial, were kept protected from light throughout the whole procedure. Methanol was HPLC grade.

\section{Instrumentation and conditions}

A HP 8453 UV-Visible Spectrophotometer with data processing system was used. UV spectra absorbance of reference and sample solutions were recorded in $10 \mathrm{~mm}$ quartz cells at $298 \mathrm{~nm}$. The solutions were prepared in methanol.

\section{Methods}

\section{Preparation of standard solutions}

The levofloxacin reference standard solution $\left(200.0 \mu \mathrm{g} \mathrm{mL}^{-1}\right)$ was prepared by accurately weighing $20.0 \mathrm{mg}$ of levofloxacin reference in a $100.0 \mathrm{~mL}$ volumetric flask. The volume was completed with methanol. This flask was sonicated for $25 \mathrm{~min}$. The above solution was diluted in a $100 \mathrm{~mL}$ volumetric flask with methnol to obtain a

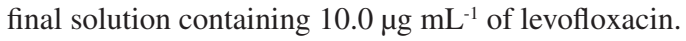

\section{Determination of maximum absorption $\lambda_{\text {ma }}$}

From the standard solution $(200.0 \mu \mathrm{g} \mathrm{mL})$ approximately $3.0 \mathrm{~mL}$ was taken and scanned from 200 to $400 \mathrm{~nm}$ with HP 8453 UV-Visible spectrophotometer. The methanol was used as blank. Levofloxacin presented maximum absorption at $298 \mathrm{~nm}$.

\section{Calibration curve}

The calibration curve was constructed by analyzing 6 different concentrations of standard solution, prepared on the same day. The range of solutions varied from 3.0 to $8.0 \mu \mathrm{g} \mathrm{mL}^{-1}$. All determinations were conducted in triplicate.

\section{Sample preparation}

\section{Levofloxacin tablets}

To analyze the concentration of levofloxacin tablets, 20 tablets of each sample were individually weighed and triturated to obtain homogeneous mixture. An amount of powder equivalent to $100.0 \mathrm{mg}$ of free base was transferred to $100.0 \mathrm{~mL}$ volumetric flask. The volume was completed with methanol. The resulting solution was sonicated during $25 \mathrm{~min}$ to facilitate proper solubilization. Aliquots of this solution were accordingly diluted with methanol, in order to obtain a solution with final concentration of $5.0 \mu \mathrm{g} \mathrm{mL} \mathrm{m}^{-1}$. All sample and standard solution were filtered through hydrophilic membrane of $0.45 \mu \mathrm{m}$ pore size - Millipore ${ }^{\circledR}$ Millex-HV filter units. All determinations were conducted in triplicate.

\section{Levofloxacin injection}

To analyze the concentration of levofloxacin injection, $5.0 \mathrm{~mL}$ of injection formulation (theoretical content $5 \mathrm{mg} \mathrm{mL}^{-1}$ ) was used for sample solution preparation. The procedure adopted for the preparation of injectable sample was similar to that described for tablets. Appropriate dilutions were made with methanol to final solution containing $5.0 \mu \mathrm{g}$ $\mathrm{mL}^{-1}$ of drug as free base. All determinations were conducted in triplicate.

\section{Method validation}

\section{Linearity}

The linearity was determined by plotting concentration against corresponding absorbance. The calibration curve was defined in the concentration interval in which the intensity of the spectrophotometer response was linearly proportional to the concentration of the analyzed substance:

$A=a \cdot C+b$

where $A$ is the absorbance; $C$, concentration of sample; $a$, slope of the curve; and, $b$, y intercept of the curve.

The linearity was evaluated by linear regression analysis, which was calculated by the least square regression method and the correlation coefficient $(r)$ indicated the linearity of the method.

\section{Precision}

The intra-day precision was determined by analyzing the samples of levofloxacin at concentrations of $5.0 \mu \mathrm{g} \mathrm{mL} \mathrm{m}^{-1}$. Determinations were performed with ten replicates on the same day. The precision is expressed as relative standard deviation (RSD) amongst responses. In order to be considered precise, the RSD of the method should be less than $2.0 \%$.

\section{Accuracy}

The accuracy of the method was evaluated through the recovery test. Recovery tests were performed by adding known amounts of standard solutions to samples followed by analyses using the proposed method. Aliquots of standard and samples solutions were transferred to $10 \mathrm{~mL}$ volumetric flasks and final volumes were completed with methanol. The percentage of recovery $(\mathrm{R})$ was calculated as indicated by Association of Official Analytical Chemists International: ${ }^{16}$

$R=\left[\left(C_{F}-C_{U}\right) / C_{A}\right] \times 100$

where $C_{F}$ represents the concentration of analyte measure in fortified test sample; $C_{U}$, the concentration of analyte measure in unfortified test sample; and, $C_{A}$, the concentration of analyte added to fortified test sample.

Specificity

Specificity is the ability of the method to accurately measure a compound in the presence of other components such as impurities, degradation products and matrix components. The specificity of the proposed method was evaluated through the analysis of a placebo solution, which it was prepared with the excipients of the pharmaceutical formulation. Thus, the mixture of component inert was prepared in their usual concentration employed in tablets than the method was applied in order to check if any component of the formulation could generate a response or a read with absorption band similar to the drug.

\section{Limit of detection and limit of quantitation}

The limit of detection (LOD) and limit of quantitation (LOQ) were calculated according to International Conference on Harmonization guidelines: ${ }^{17}$

$L O D=3.3 \cdot S D_{b} / a$

$L O Q=10.0 \cdot S D_{b} / a$

where $S D_{b}$ represents the standard deviation of y-intercept and $a$ is the slope of calibration curve.

\section{Statistical analysis}

All statistical analysis was calculated using spreadsheet programs and SPSS Software. ${ }^{18}$ 


\section{RESULTS AND DISCUSSION}

Levofloxacin was analyzed by proposed UV spectrophotometric method in tablets and injections. The calibration curve showed linearity over a concentration range from 3.0 to $8.0 \mu \mathrm{g} \mathrm{mL}^{-1}$. The linearity can be defined by following equation $A=0.0981 C+0.0019$ (Figure 2 ), where $A$ and $C$ are levofloxacin absorbance and concentration, respectively. The correlation coefficients of the curve obtained with linear regression method were 0.9999 .

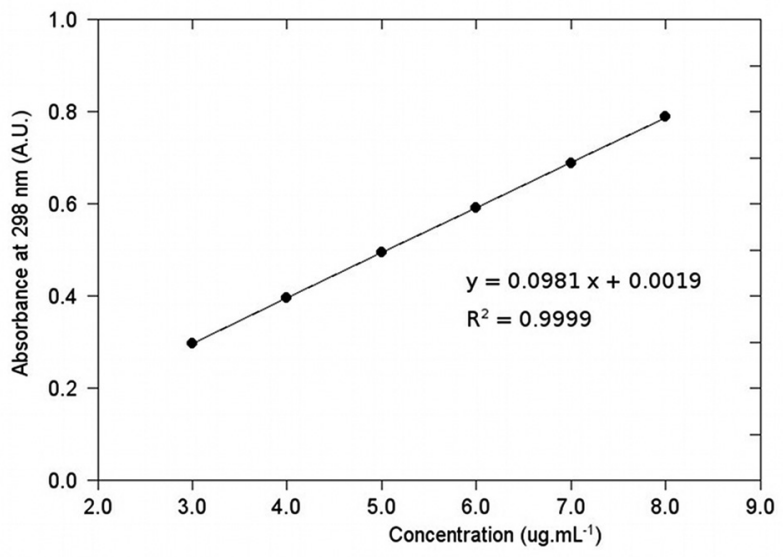

Figure 2. Calibration curve for Levofloxacin from standard solutions in the range 3.0 to $8.0 \mu \mathrm{g} \mathrm{mL}^{-1}$

The RSD amongst ten measurements for each sample found to be 0.45 and $0.34 \%$ for tablets and injection forms, respectively (Table 1). The percentages content were $98.32 \pm 0.01 \%$ and $99.20 \pm 0.01 \%$ for tablets and injection forms, respectively (Table 1).

Table 1. Statistical data obtained in the analysis of samples by using the proposed spectrophotometer method

\begin{tabular}{lcccc}
\hline $\begin{array}{l}\text { Pharmaceutical } \\
\text { Dosage Form }\end{array}$ & $\begin{array}{c}\text { Declared } \\
\text { theoretical } \\
\text { concentration } \\
\left(\mu \mathrm{g} \mathrm{mL} L^{-1}\right)\end{array}$ & $\begin{array}{c}\text { Found } \\
\text { experimental } \\
\text { concentration } \\
\left(\mu \mathrm{g} \mathrm{mL}^{-1}\right)^{\mathrm{a}, \mathrm{b}}\end{array}$ & $\begin{array}{c}\text { RSD } \\
(\%)\end{array}$ & $\begin{array}{c}\text { Content } \\
(\%)^{\mathrm{b}}\end{array}$ \\
\hline Tablets $(250 \mathrm{mg})$ & 5.00 & $4.92 \pm 0.02$ & 0.45 & $98.32 \pm 0.01$ \\
$\begin{array}{l}\text { Injection } 100 \mathrm{~mL} \\
\left(5 \mathrm{mg} \mathrm{mL}^{-1}\right)\end{array}$ & 5.00 & $4.96 \pm 0.01$ & 0.34 & $99.20 \pm 0.01$ \\
\hline
\end{tabular}

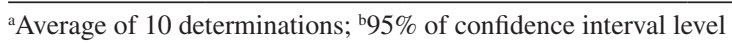
(t-Distribution)

The recovery values obtained were $101.42 \pm 0.45 \%$ and $100.34 \pm$ $0.85 \%$ for tablets and injections forms, respectively, by using Equation 2 . These results confirm accuracy of the proposed method. The percentage of recovery results are presented in Table 2.

The assays were validated by means of the analysis of variance, as described in official literature. This developed method presented no parallelism deviation and no linearity deviation $(\mathrm{P}<0.05)$. The precision and accuracy of the assay were demonstrated.

The excipients present in pharmaceutical dosage form (tablets) do not interfere in the analysis. The results prove specificity of the proposed methods for inequivocal identification of analyte in the presence of matrix compounds (excipients).

The LOD and LOQ were 0.08 and $0.25 \mu \mathrm{gL}^{-1}$, by using Equations 3 and 4, respectively.

While comparing proposed analytical method for determination of levofloxacin in pharmaceutical formulations with those reported in literature, it can be observed that:

Linearity range: reported HPLC-UV, ${ }^{7} \mathrm{CS},{ }^{9} \mathrm{CIPS},{ }^{10,11}$ and UVS, ${ }^{13}$
Table 2. Recovery data of standard solutions added to the samples analyzed by using the proposed spectrophotometer method

\begin{tabular}{lcccc}
\hline $\begin{array}{l}\text { Pharmaceutical } \\
\text { Dosage Form }\end{array}$ & $\begin{array}{c}\text { Fortified } \\
\text { theoretical } \\
\text { concentration } \\
\left(\mu \mathrm{g} \mathrm{mL}^{-1}\right)^{\mathrm{a}}\end{array}$ & $\begin{array}{c}\text { Found } \\
\text { experimental } \\
\text { concentration } \\
\left(\mu \mathrm{g} \mathrm{mL}^{-1}\right)^{\mathrm{b}}\end{array}$ & \multicolumn{2}{c}{ Recovery (\%) } \\
\hline Tablets & 6.00 & 5.96 & 100.68 & Average $^{\mathrm{d}}$ \\
$(250 \mathrm{mg})$ & 7.00 & 7.02 & 101.99 & $101.42 \pm$ \\
& 8.00 & 8.02 & 101.59 & 0.45 \\
Injection & 6.00 & 5.98 & 101.41 & \\
$100 \mathrm{~mL}$ & 7.00 & 6.96 & 100.70 & $100.34 \pm$ \\
$\left(5 \mathrm{mg} \cdot \mathrm{mL}^{-1}\right)$ & 8.00 & 7.88 & 98.92 & 0.85 \\
\hline
\end{tabular}

${ }^{a}$ Theoretical Sample Concentration: $3.00 \mu \mathrm{g} \mathrm{mL}^{-1}$; ${ }^{\mathrm{b}}$ Average of 3 determinations; " Concentration of analyte measured in unfortified test sample $\left(\mathrm{C}_{\mathrm{U}}\right)$ was $2.94 \mu \mathrm{g} \mathrm{mL}^{-1} ;{ }^{\mathrm{d}} 95 \%$ of confidence interval level (t-Distribution)

methods presented significantly higher linearity range, 20.0, 25.0, 29.65 , and $10.00 \mu \mathrm{g} \mathrm{mL}{ }^{-1}$, respectively;

Accuracy: all reported methods are equally accurate;

Precision: CIPS method using bromophenol blue or bromocresol green, ${ }^{10,12}$ presented RSD values near $0.06 \%$. While SF, ${ }^{9} \mathrm{UVS},{ }^{13}$ and

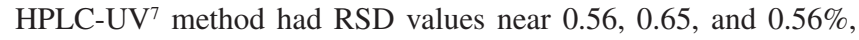
respectively;

LOD and LOQ: the reported LOD and LOQ values in the literature are high, that makes our method more sensitive.

It is important to observe that only two methods ${ }^{7,9}$ were fully validated and applied in the analysis of Levofloxacin in tablets and injection formulations.

\section{CONCLUSION}

In this study, the developed and validated UV-spectrophotometric alternative method for the determination of levofloxacin in pharmaceutical formulations has the advantage of being fast, simple, cost-effective with high precision, and accuracy. These advantages encourage the application of this method in routine analysis of levofloxacin.

\section{ACKNOWLEDGMENT}

The authors gratefully thank "Fundação de Apoio ao Desenvolvimento de Ensino, Ciência e Tecnologia do Estado de Mato Grosso do Sul (FUNDECT - Processo 41/100.140/2006)", and "Coordenação de Aperfeiçoamento de Pessoal de Nível Superior (CAPES)" for financial support.

\section{REFERENCES}

1. Burhenne, J.; Ludwig, M.; Spiteller, M.; Chemosphere 1999, 38, 1279.

2. Hernández-Arteseros, J. A.; Barbosa, J.; Compañó, R.; Prat, M. D.; J. Chromatogr., A 2002, 945, 1.

3. Kothekar, K. M.; Jayakar, B.; Khandhar, A. P.; Mishra, R. K.; Eurasian J. Anal. Chem. 2007, 2, 21.

4. Belal, F.; Al-Majed, A. A.; Al-Obaid, A. M.; Talanta 1999, 50, 765.

5. Ball, P.; Curr. Ther. Res. Clin. E 2003, 64, 646.

6. Nakayama, I.; Yamaji, E.; Anaerobe 2003, 9, 71.

7. Santoro, M. I. R. M.; Kassab, N. M.; Singh, A. K.; Kedor-Hackmam, E. R. M.; J. Pharm. Biomed. Anal. 2006, 40, 179.

8. Wang, Y.; Yu, K.; Wang, S.; Spectrochim. Acta, Part A 2006, 65, 159.

9. Salem, H.; Am. J. Appl. Sci. 2005, 2, 719.

10. Ashour, S.; Al-Khalil, R.; Il Farmaco 2005, 60, 771. 
11. El-Brashy, A. M.; El-Sayed Metwally, M.; El-Sepai, F. A.; Il Farmaco 2004, 59, 809 .

12. Sivasubramanian, L.; Kasi, S.; Sivaraman, V.; Senthil, K. K.; Muthukumaran, A.; Raja, T. K.; Indian J. Pharm. Sci. 2004, 66, 799.

13. Shirkhedkar, A. A.; Surana, S. J.; Pak. J. Pharm. Sci. 2009, 22, 301.

14. United States Pharmacopoeia, $30^{\text {th }}$ ed., United States Pharmacopeial Convention: RockVille, 2007.

15. British Pharmacopoeia, Health Ministers: London, 2008.
16. Association of Official Analytical Chemists: Official Methods of Analysis of AOAC International, $17^{\text {th }}$ ed., AOAC International: Gaithersburg, 2002, vol. 1, P. XX.

17. International Conference on Harmonization (ICH): Validation of Analytical Procedures: Text and Methodology, Geneva, IFPMA, 1996; http://www.ich.org/LOB/media/MEDIA417.pdf , accessed September 2009.

18. SPSS Inc.; SPSS for Windows; Rel. 11.0.1; Statistical Package; United State of American, 2001. 